\title{
sciforum
}

\section{Plasma Based Water Purifier: Design and Testing Of Prototype with Different samples of water}

\author{
SURAJM(m.suraj@st.hanze.nl) $)^{1, *}$, ANURADHAT(anuradha-aiht@gmail.com) ${ }^{\text {I\# }}$
}

\author{
${ }^{1}$ Department of Electrical and Electronics Engineering, Anna University (AIHT) \\ * Corresponding Author \\ \# This authors contributed as a project coordinator.
}

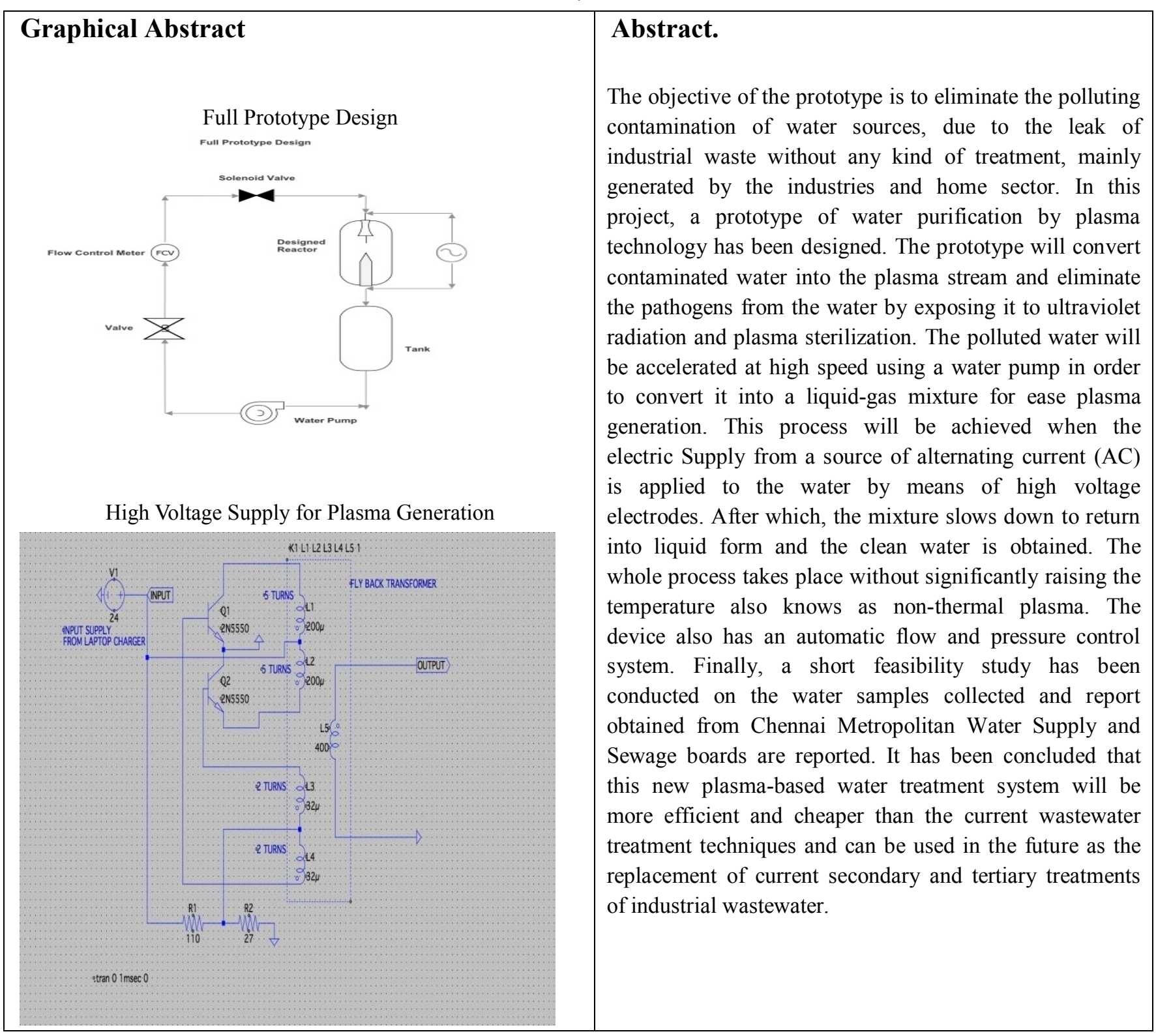




\section{Introduction}

Nowadays, demand on the environment quality has rapidly increased. It is considered sharply watched and an important subject is water environment, since its harmlessness for the human race and nature in general. The wastewater releasing from chemical industries and households most often contain harmful compounds. These compounds can be dangerous or even toxic for the Earth's environment, and they can even cause several problems to the human race. Therefore it is very important to purely observe these compounds in water, and also to remove them from this environment. The best way is to prevent the contamination in water by saying not to use harmful compounds in the households and industry. But this not possible at all so, it is important to know how water can be treated to become harmless[1]. For the water treatment, different methods of water treatment have been used for centuries and developed. These treatment methods are divided into four different methods: physical, chemical and biological.

Biological methods are the wider one for water treatment techniques. The main advantage is low operative cost and most widely used by municipals and industries. The main disadvantage is not a very efficient process for removal of harmful pollutant. Moreover, the process of biological degradation of pollutants is significantly slower than other processes[6]. Physical methods are based on a pure mechanical separation in which waste products from water by a particular supporting system like charcoal and filter paper. The advantage of this process is there is no chemical involved. On the other hand, physical methods are not sufficient for the removal of most of the hazardous compounds, especially on the organic basic compound. In conflict to the physical method, chemical oxidation processes are more often used for the treatment of water which is contaminated by organic compounds. The most common oxidants are chlorine dioxide, chlorine, ozone, and potassium permanganate. But this reagent forms the hazardous by-products[4]. So this problem is solved by the ozonisation process which is efficient but more costly in comparison.

Plasma in the liquid can be generated by the different electrode configuration in the coaxial reactor design; with the $\mathrm{A} / \mathrm{C}$ voltage is applied for the discharge ignition to take place. This discharge in the liquid will initiate the various chemical and physical reactions which is used for the purification of water. The electric discharge will initiate some of the physical processes like a strong electric field, UV radiation and formation of shockwaves. On the other side, chemically reaction such as radicals, high energetic electrons, ions and molecules with high oxidation potential is the most desirable chemical process[1]. Based on the above process this could be used for the treatment of the wastewater from the factory without the use of any additional chemical. Through this process, not only the organic pollutant but also the inorganic pollutant can be treated. Another use of plasma is in the plasma sterilization (killing microorganism) and surface treatment (Hospital waste).

\section{Plasma in Liquid}

An application of high electric energy into the system leads intensive movement of the particle which collides with each other and forms the change ions. Finally plasma is generated due to this high charge particle. In general, the plasma which is generated in the gas or liquid phase leads to the generation of the non thermal plasma, which has been used for the plasma, based water purifier [3].

Plasma generation dependent on the environment in which the plasma is ignited. Plasma in liquid is depending on the three main factors:

- Higher is the density of the medium induces the high collision frequency and low charge particle mobility.

- high polarity and dielectric strength of water molecules which lead to the creation of dipole momentum in the applied electric field and inhomogeneous areas in the vicinity of an electrode surface

- Discharge creation in the liquid phase is a presence of ions and their different mobility in a solution.

From the above facts we can conclude that for the plasma to get generated by amplification of the applied electric field in order to achieve high electric intensity sufficient for the discharge breakdown. For the breakdown of liquids appears if the electric intensity of $1 \mathrm{MV} / \mathrm{cm}$ is reached, which is likely not possible. But we know In the gas phase, the required electric intensity is about $30 \mathrm{kV} / \mathrm{cm}$ at atmospheric pressure. By using the above gas phase fact now by using the high pressure pump and nozzle liquid-gas mixture is created and then the voltage is applied. From their plasma is generated[1] 


\section{Prototype Design}

\subsection{Process Involved}

A reactor model was design. The main advantage with the prototype, since it produces the non thermal plasma which will not increase the temperature of the water, which intestinally neglect the use of any cooling system. The device featured a pump and a nozzle which accelerates the pollutant water to high speed to convert it into a liquid-gas mixture in order to transform it into plasma. The electrical discharge is applied to the water by mode of two sharp copper electrodes from a pulsating DC power supply. Later the mixture is decelerated and returns it into liquid state to obtain clean water, without a temperature rise[3].

\subsection{Main Design Parameters}

Reactor: Coaxial geometry with copper electrode, $22 \mathrm{~cm}$ in length and diameter of $9 \mathrm{~cm}$, Hollowed pyrex tube.

Power Supply: output A/C, $34 \mathrm{Kv}, 10 \mathrm{khz}$

Input $\mathrm{D} / \mathrm{C}, 24 \mathrm{v}$ (Laptop charger)

Nozzle: $\quad 201 / \min @ 70 p s i$

Pump: $\quad 1$ HP Single Phase

Tank: $\quad 501$ Tank

Other $\quad 1$ solenoid valve

Full Prototype Design

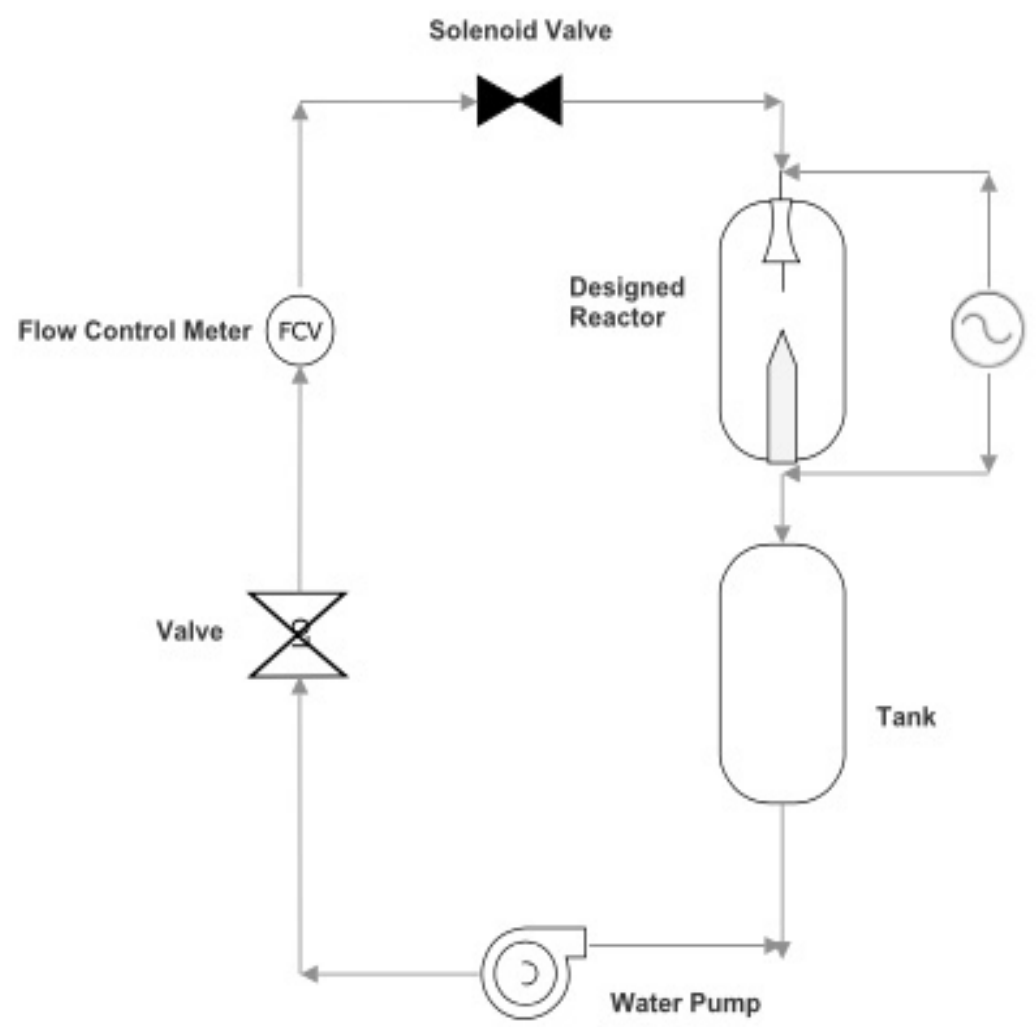

Figure 1. Full Schematics Diagram Of Water Purifier 


\subsection{Experimental Reactor Device}

The first prototype of discharge reactor was constructed at our laboratory and it has been used in experiments. Discharge reactor used for the plasma generation in water solution has some basic geometry base called as coaxial configuration. The reactor is divided by the dielectric barrier (water) between the two electrode one with the high voltage and other grounded. The main body of the reactor is made of Pyrex and it can fill with $500 \mathrm{ML}$ of water. The attachment of a nozzle made perfect to create liquid-gas mixture. Majorly give aggressive advantage over other reactors based on parallel plate's configuration.

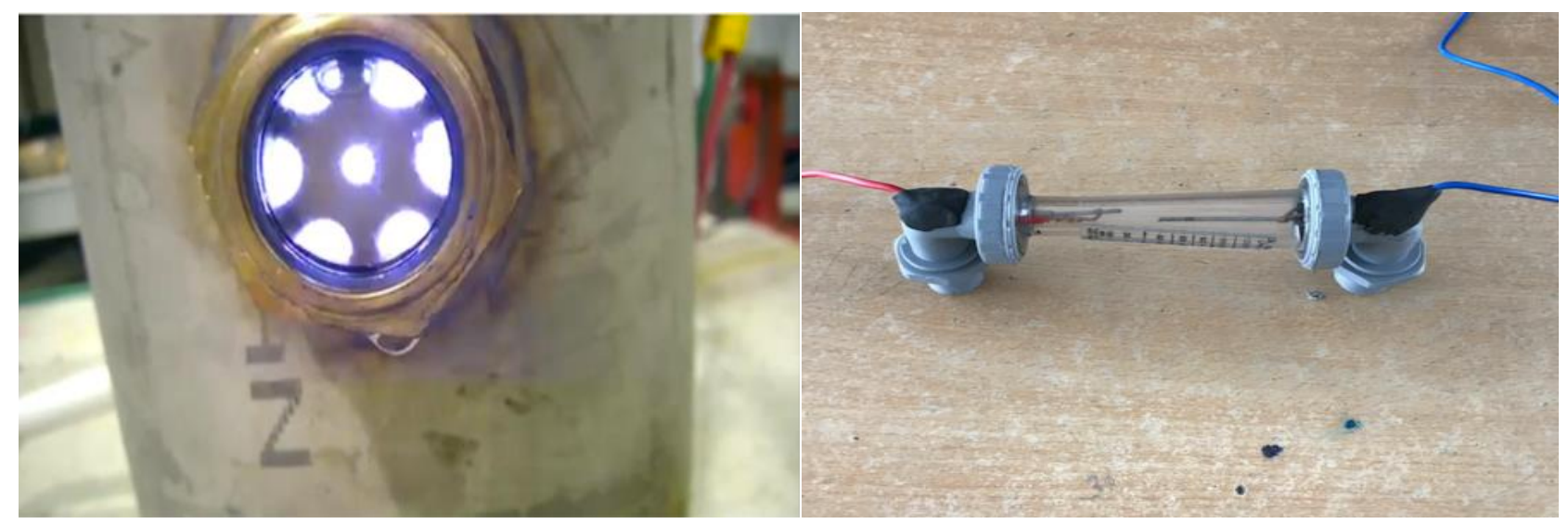

Figure 2. Photograph of the simple discharge reactor, which is used mainly for plasma diagnostics

\subsection{High Voltage Sources}

The voltage source used for the discharge generation is the Non pulsating DC voltage with high frequency about $25 \mathrm{KHZ}$. The simplified scheme of the DC HV source is shown in Figure. By a simple setup it is possible to generate 30KV from a flyback transformer.

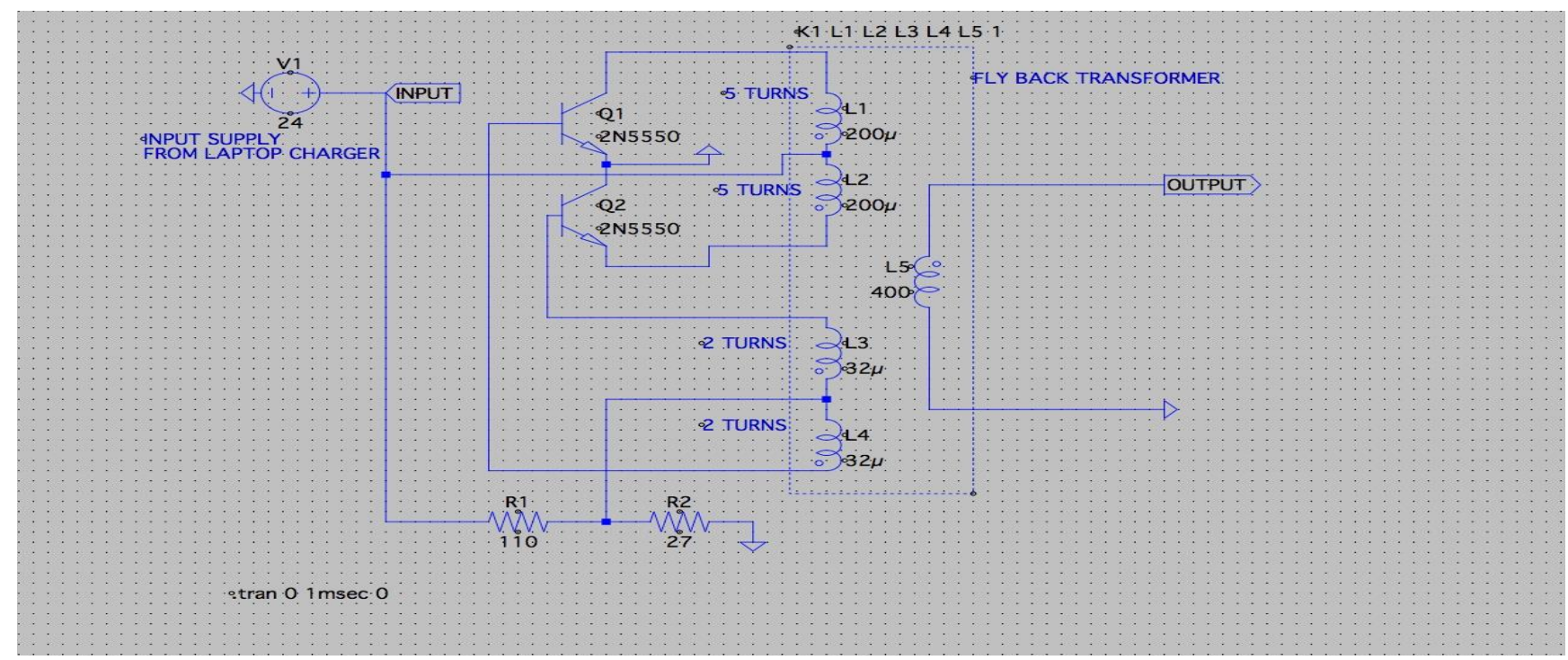

Figure 3. Simplified scheme of DC HV source connected to the discharge reactor

The HF high voltage source was also specially constructed to supply the plasma devices by high frequency power. It consists of DC sources of 24 Volt for the simplicity laptop charger is enough, which is coupled with the flyback transformer driver circuit and at the end of the flyback transformer $30 \mathrm{kv}$ is obtained. Efficiency of the source is approximately $80 \%$. 


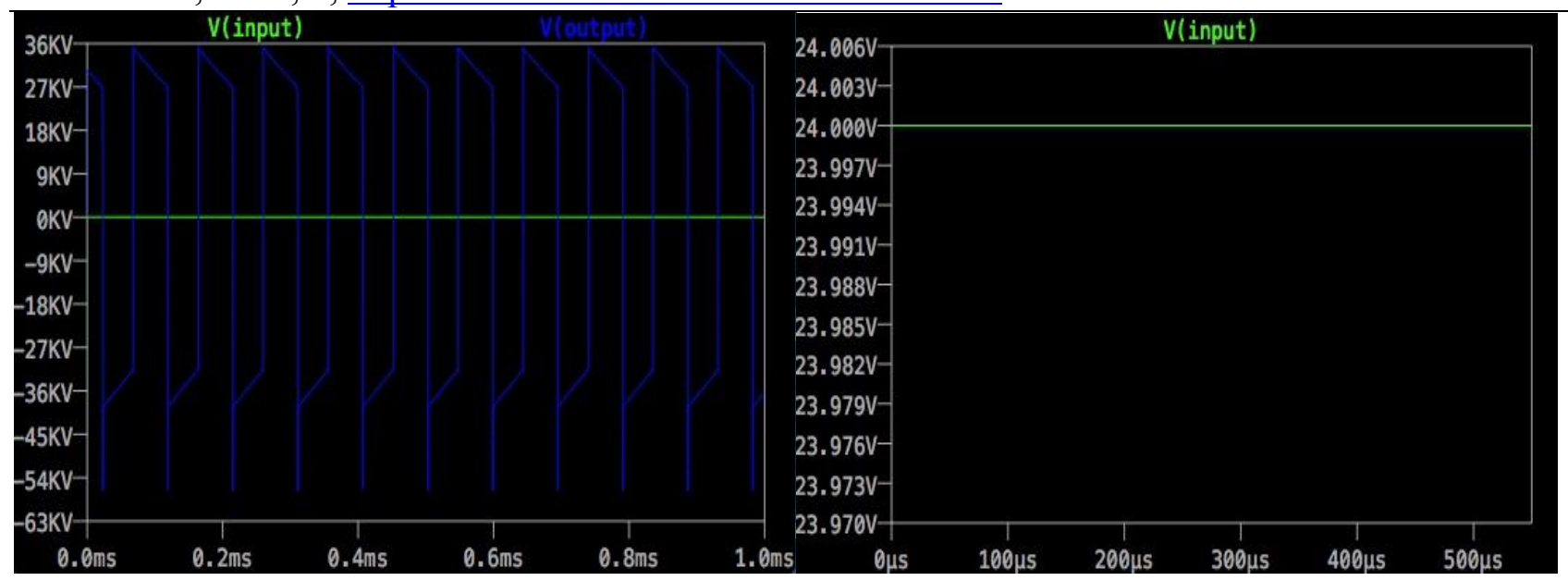

Figure 4. Typical Input And Output Voltage Simulation in LTspice

\section{Water Sample solutions}

After design of prototype, work is to check the various water solution interactions with water. For this purpose tap water is used to support a required conductivity. In some experiments organic and dye are dissolved. The solution is pumped in the reactor. Subsequently, an appropriate high voltage source is connected to the plasma reactor.

Generally, the experimental solutions consist of following item combinations:

a) Water + organic dye

b) Water + humic acids.

\subsection{Organic Dye (Beetroot Dye Extract)}

In order to study the decomposition of the dye in water by the plasma, organic dye selected is BeetrootExtract. The advantage of the dye is that decomposition rate is proportional to the decoration and this effect is visible to the eyes. Here only problem comes up with the formation of by-products during the dye interaction with plasma.

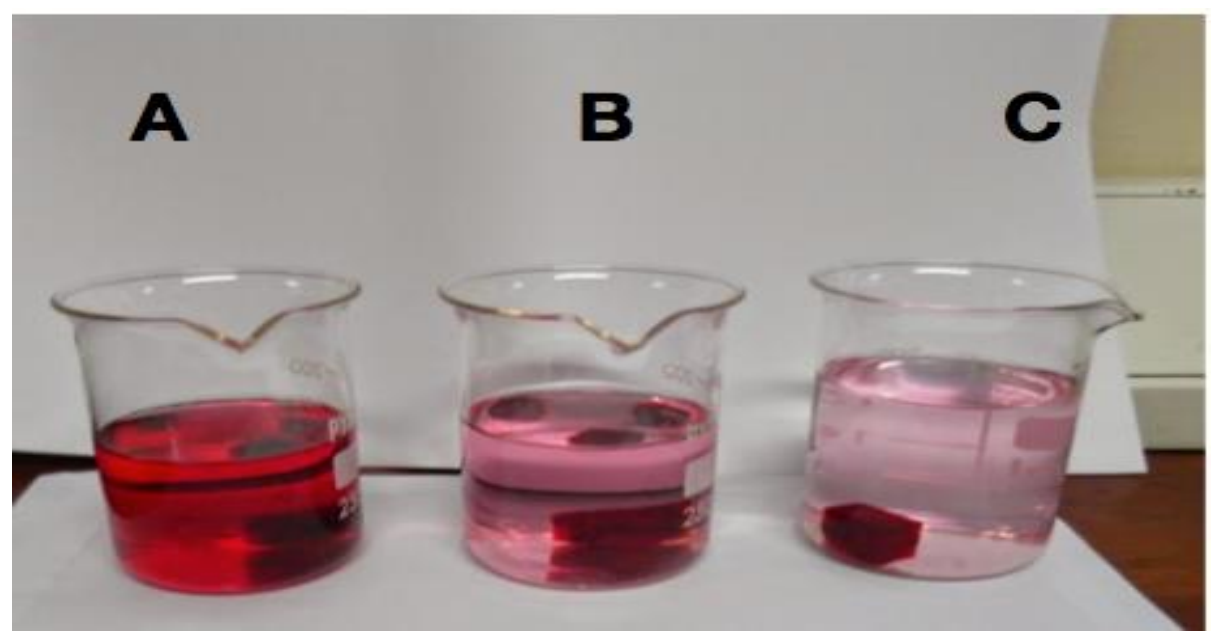

Figure 5. Dye Extracted from Beetroot

\subsection{Humic Acid}

The organic compound is the humic acids which are organic matter distributed in terrestrial soil, natural water, and sediment. Humic substances are formed by the microbial degradation of dead plant matter, such as lignin and charcoal. Mixture consists of a commercial product HUMIN-P 775 dissolved in deionizer water for the testing. Concentration of humic acids in this solution is $1.9 \mathrm{mg} / \mathrm{L}$. 


\section{Observation}

Ignition of plasma in water solutions requires a configuration of the plasma reactor as well as proper experimental conditions. Both the device parameters and water properties are important in the process of the discharge creation. This part of work deals mainly with the DC non-pulsed voltage. The important processes such are bubble formation and electrolysis are detected as well. According to the breakdown theories in water, the discharge ignition can start in bubbles of evaporated liquid or by the direct ionization of water molecules. Due to a high potential gradient between the outer and inner bubble surface, the ionization of water vapors occurs and thus the discharge is ignited.

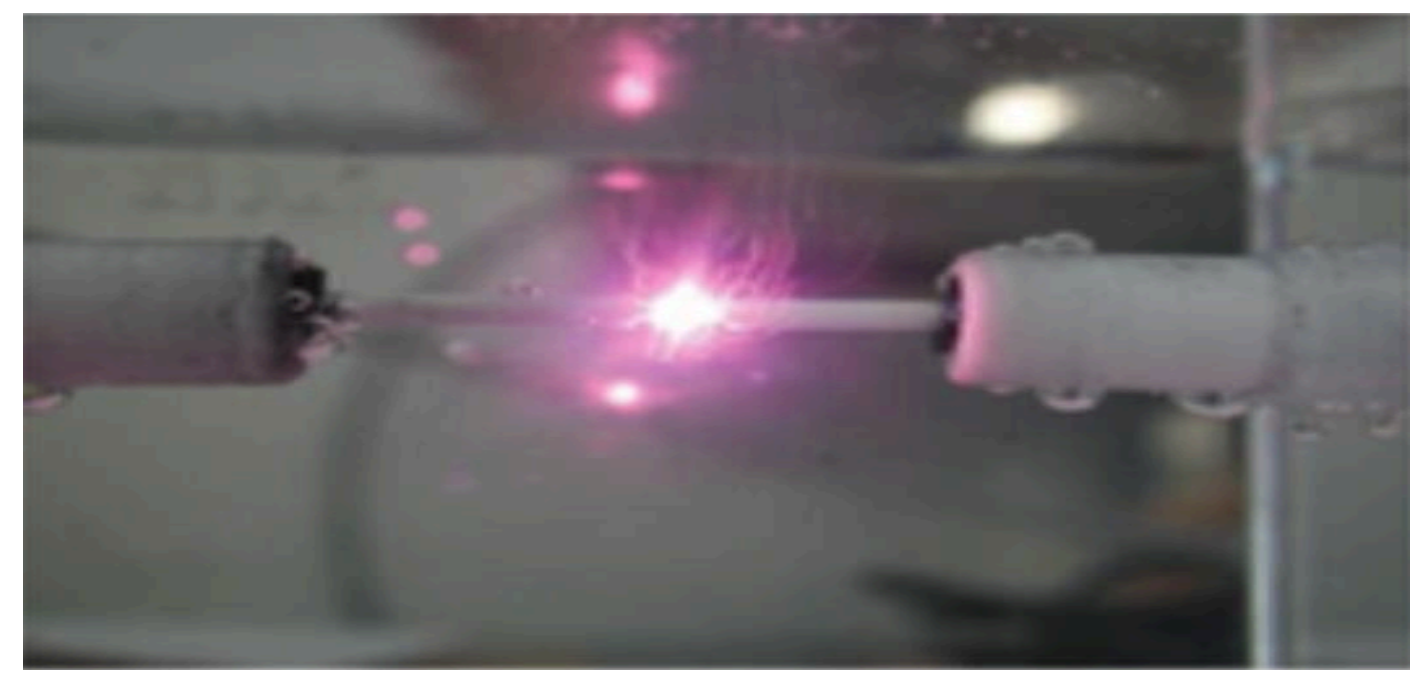

Figure 6. Plasma streamers

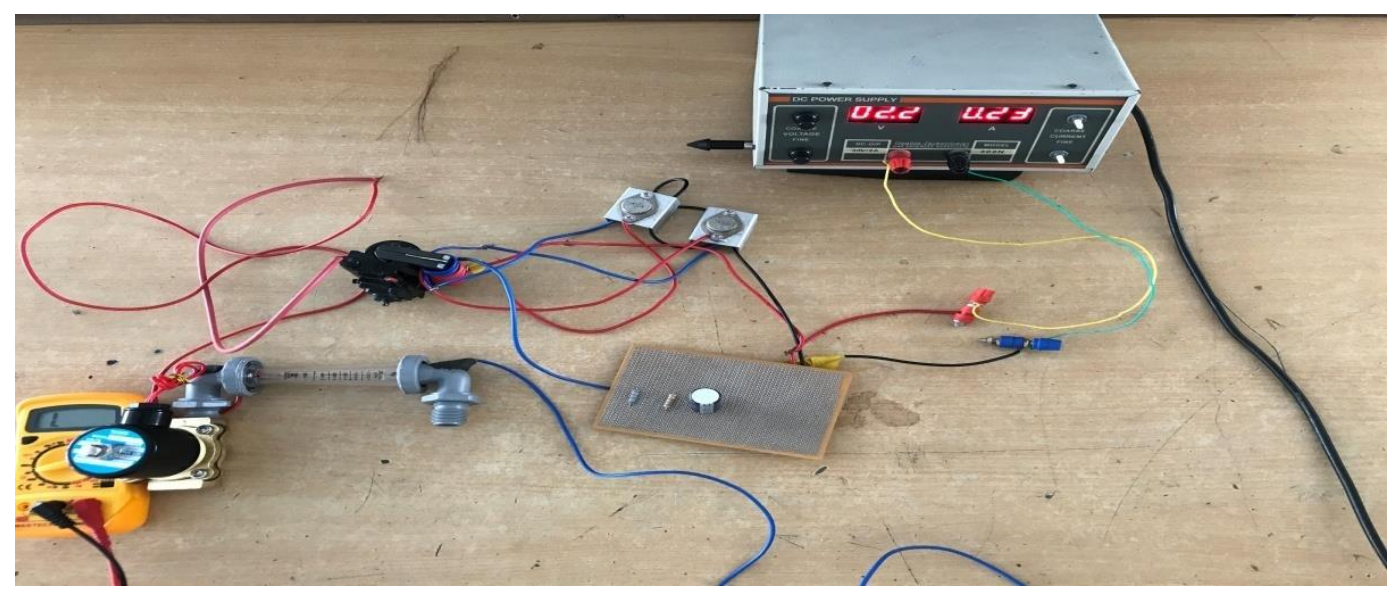

Figure 7. Overall Rough Experimental Setup

The following process can be seen during the plasma in water:

- Plasma Streamers

- Uv Radiation

- Ozone

- Plasma Sterilisation 


\section{Result}

A short feasibility study has been conducted on the water samples collected and report obtained from Chennai Metropolitan Water Supply and Sewage board is reported. It has been concluded that this new plasma based water treatment system will be more efficient and cheaper than the current waste water treatment techniques. .All the experiment common solution was found, as the $\mathrm{pH}$ is maintained within the limit. After plasma treatment water has become more suitable for drinking.

Table 1. Experiment Results of Normal Water Before And Plasma Treatment.

\begin{tabular}{|c|c|c|c|c|}
\hline \multicolumn{5}{|c|}{ Chennai Metropolitan Water Supply and Sewage board } \\
\hline $\begin{array}{l}\text { Physical and chemical } \\
\text { examination }\end{array}$ & $\begin{array}{l}\text { Tap Water } \\
\text { Before Plasma } \\
\text { Discharge }\end{array}$ & $\begin{array}{l}\text { Tap Water } \\
\text { After Plasma } \\
\text { Discharge }\end{array}$ & $\begin{array}{l}\text { IS:10500-2012 } \\
\text { Acceptable } \\
\text { limits }\end{array}$ & $\begin{array}{l}\text { IS: } 10500-2012 \\
\text { Permissable } \\
\text { limit }\end{array}$ \\
\hline Colour & $\begin{array}{l}\text { Colourless } \\
\text { And Clear }\end{array}$ & $\begin{array}{l}\text { Colourless } \\
\text { And Clear }\end{array}$ & Agreeable & Agreeable \\
\hline Odour & $\mathrm{NIL}$ & NIL & & \\
\hline Turbidity & 0.1 & 0.1 & 1 & 10 \\
\hline $\begin{array}{l}\text { Total Dissolved Solids At } 105 \\
\text { C (mg/l) }\end{array}$ & 1140 & 475 & 500 & 2000 \\
\hline Calcium (As Ca) (Mg/L) & 124 & 32 & 75 & 200 \\
\hline Magnesium (As Mg) (mg/L) & 58 & 17 & 30 & 100 \\
\hline $\begin{array}{l}\text { Total Hardness (As CACO3) } \\
(\mathrm{Mg} / \mathrm{L})\end{array}$ & 550 & 148 & 200 & 600 \\
\hline Chlorides (As Cl) (Mg/L) & 260 & 144 & 250 & 1000 \\
\hline $\begin{array}{l}\text { Ammoniacal Nitrogen (As N) } \\
(\mathrm{Mg} / \mathrm{L})\end{array}$ & 0.040 & 0.040 & - & - \\
\hline $\begin{array}{l}\text { Oxygen Absorbed (Tidy's } 4 \\
\text { hour Test) }(\mathrm{Mg} / \mathrm{L})\end{array}$ & 0.75 & 0.45 & - & - \\
\hline $\begin{array}{l}\text { Hydrogen Ion Concentration } \\
(\mathrm{pH})\end{array}$ & 7.2 & 6.5 & 6.5 to 8.5 & 6.5 to 8.5 \\
\hline Fluorides (As F) (Mg/L) & 0.10 & 0.10 & 1.0 & 1.5 \\
\hline
\end{tabular}

Table 2. Experiment Results of Water+Dye Before And Plasma Treatment.

\begin{tabular}{|c|c|c|c|c|}
\hline \multicolumn{5}{|c|}{ Chennai Metropolitan Water Supply and Sewage board } \\
\hline $\begin{array}{l}\text { Physical and chemical } \\
\text { examination }\end{array}$ & $\begin{array}{l}\text { Dye+Water } \\
\text { Before Plasma } \\
\text { Discharge }\end{array}$ & $\begin{array}{l}\text { Dye+Water } \\
\text { After Plasma } \\
\text { Discharge }\end{array}$ & $\begin{array}{l}\text { IS:10500-2012 } \\
\text { Acceptable } \\
\text { limits }\end{array}$ & $\begin{array}{l}\text { IS:10500-2012 } \\
\text { Permissable } \\
\text { limit }\end{array}$ \\
\hline Colour & Reddish & $\begin{array}{l}\text { Colourless } \\
\text { and Clear }\end{array}$ & Agreeable & Agreeable \\
\hline Odour & Earthy & NIL & & \\
\hline Turbidity & 69 & 0.5 & 1 & 10 \\
\hline $\begin{array}{l}\text { Total Dissolved Solids At } 105 \\
\mathrm{C}(\mathrm{mg} / \mathrm{l})\end{array}$ & 975 & 975 & 500 & 2000 \\
\hline Calcium (As Ca) (Mg/L) & 92 & 96 & 75 & 200 \\
\hline Magnesium (As Mg) (mg/L) & 41 & 70 & 30 & 100 \\
\hline $\begin{array}{l}\text { Total Hardness (As CACO3) } \\
(\mathrm{Mg} / \mathrm{L})\end{array}$ & 400 & 530 & 200 & 600 \\
\hline Chlorides (As Cl) $(\mathrm{Mg} / \mathrm{L})$ & 330 & 200 & 250 & 1000 \\
\hline $\begin{array}{l}\text { Ammoniacal Nitrogen (As N) } \\
(\mathrm{Mg} / \mathrm{L})\end{array}$ & 0.090 & 0.030 & - & - \\
\hline $\begin{array}{l}\text { Oxygen Absorbed (Tidy's } 4 \\
\text { hour Test) }(\mathrm{Mg} / \mathrm{L})\end{array}$ & 3.43 & 0.24 & - & - \\
\hline $\begin{array}{l}\text { Hydrogen Ion Concentration } \\
(\mathrm{pH})\end{array}$ & 8.6 & 7.5 & 6.5 to 8.5 & 6.5 to 8.5 \\
\hline Fluorides (As F) (Mg/L) & 0.10 & 0.10 & 1.0 & 1.5 \\
\hline
\end{tabular}


Table 3. Experiment Results of Water+Humic acid Before And Plasma Treatment..

\begin{tabular}{|c|c|c|c|c|}
\hline \multicolumn{5}{|c|}{ Chennai Metropolitan Water Supply and Sewage board } \\
\hline $\begin{array}{l}\text { Physical and chemical } \\
\text { examination }\end{array}$ & $\begin{array}{l}\text { Humic acid } \\
+\quad \text { Water } \\
\text { Before Plasma } \\
\text { Discharge }\end{array}$ & $\begin{array}{l}\text { Humic acid } \\
+\quad \text { Water } \\
\text { After Plasma } \\
\text { Discharge }\end{array}$ & $\begin{array}{l}\text { IS:10500-2012 } \\
\text { Acceptable } \\
\text { limits }\end{array}$ & $\begin{array}{l}\text { IS:10500-2012 } \\
\text { Permissable } \\
\text { limit }\end{array}$ \\
\hline Colour & Yellowish & $\begin{array}{l}\text { Colourless } \\
\text { and Clear }\end{array}$ & Agreeable & Agreeable \\
\hline Odour & Earthy & $\mathrm{NIL}$ & & \\
\hline Turbidity & 35 & 0.4 & 1 & 10 \\
\hline $\begin{array}{l}\text { Total Dissolved Solids At } 105 \\
\text { C (mg/l) }\end{array}$ & 890 & 1220 & 500 & 2000 \\
\hline Calcium (As Ca) (Mg/L) & 72 & 220 & 75 & 200 \\
\hline Magnesium (As Mg) (mg/L) & 53 & 56 & 30 & 100 \\
\hline $\begin{array}{l}\text { Total Hardness (As CACO3) } \\
(\mathrm{Mg} / \mathrm{L})\end{array}$ & 400 & 780 & 200 & 600 \\
\hline Chlorides (As Cl) (Mg/L) & 320 & 430 & 250 & 1000 \\
\hline $\begin{array}{l}\text { Ammoniacal Nitrogen (As N) } \\
(\mathrm{Mg} / \mathrm{L})\end{array}$ & 0.048 & 0.030 & - & - \\
\hline $\begin{array}{l}\text { Oxygen Absorbed (Tidy's } 4 \\
\text { hour Test) }(\mathrm{Mg} / \mathrm{L})\end{array}$ & 2.92 & 0.30 & - & - \\
\hline $\begin{array}{l}\text { Hydrogen Ion Concentration } \\
(\mathrm{pH})\end{array}$ & 8.6 & 7.5 & 6.5 to 8.5 & 6.5 to 8.5 \\
\hline Fluorides (As F) $(\mathrm{Mg} / \mathrm{L})$ & 0.10 & 0.10 & 1.0 & 1.5 \\
\hline
\end{tabular}

\section{Conclusion}

As mentioned, human must treat the wastewater in order to ensure the protection of the environment. It is possible that, due to the high cost and maintenance of traditional treatment plants, people find it difficult to properly treat the contaminated waters. Although experimental data will only be definitive the device is built and tested, it is intended that with the proposed device, cost, maintenance and space could decrease significantly. Which could lead industries especially from developing countries to reconsider discharge untreated sewage. Finally, the ideal state is to offer a whole new costimprovement, effective, efficient and innovative concept on wastewater plants, for example, by using plasma which could segregate and retain certain organic/inorganic components from the water, and then, eliminate biodegradable organic matter (like microorganisms, bacteria, virus, etc.) by means of the proposed reactor.

\section{References}

1. Beverly Richard, P. (2012), 'Water Treatment Process Monitoring and Evaluation', American Water Works Association. Denver, USA. ISBN: 978- 1583218587.

2. Chiuderi, C., Velli, M. (2015), 'Basics of Plasma Astrophysics', Springer- Verlag,Italy. ISBN 978-88-470-5279-6.

3. Chu,P.K., Lu, XinPei. (2013), 'Low Temperature Plasma Technology: Methods and Applications', CRC Press, Taylorand Francis Group, Florida. ISBN 978-1-4665-0990-0.

4. Deng, Y., Zhao, R. (2015), 'Advanced Oxidation Processes (AOPs) in Wastewater Treatment', Springer - Current Pollution Reports, Vol. 1, No. 3, pp 167- 176. DOI:10.1007/s40726-015-0015-z.

5. Freeman, M. H. (1997), 'Standard Handbook of Hazardous Waste Treatment and Disposal', 2nd edition, McGrawHill Book Company, New York. ISBN: 0-07-022044-1.

6. Tushar Kanti Sen. (2015), 'Physical, Chemical and Biological Treatment Processes for Water and Wastewater', NovaScience Publishers Inc, New York. ISBN: 978-1634833967. 
